\title{
Structural change and output volatility reduction in OECD countries: evidence of the Second Great Moderation
}

\author{
Hasan Engin Duran*
}

\author{
*Correspondence: \\ enginduran@iyte.edu.tr \\ City and Regional Planning \\ Department, Izmir Institute \\ of Technology (Turkey), Urla, \\ Izmir, Turkey
}

\begin{abstract}
In this article, we provide new, novel evidence for a more recent structural break (in 2010) indicating a greater moderation of output volatility compared to the well-known break during the mid-1980s. The period of analysis runs from 1962Q2 to 2018Q3. It covers 26 OECD countries. In terms of methodology, it has mainly been used as the measures of conditional and unconditional volatility and procedures of structural break detection (Inclan-Tiao test and autoregressive conditional heteroscedasticity model). As a result, it has been found that output greatly stabilized following the structural break at 2010Q1 in the post-era of 2008/09 global financial crisis. Moreover, output stabilization is robustly evident for 24 (out of 26) OECD countries. From a political standpoint, it is implied that the Keynesian view may be influential in this moderation. Government expenditures and fiscal programs, regulations of financial markets against the sub-prime lending and limitations to trade of mortgage-backed securities might have been the main driver of stability. Rapid improvement of digitalization and technical productivity may be regarded as another relevant reason that might have contributed to the stabilization process.
\end{abstract}

Keywords: Great Moderation, Structural breaks, Volatility

JEL Classification: E32, F44, E00

\section{Introduction}

The recently popular term "Great Moderation" refers to a significant reduction in output volatility that occurred during the mid-1980s in US (United States) and other countries (Bernanke 2004; Clarida et al. 2000; McConnell and Perez-Quiros 2000; Stock and Watson 2002, 2003, 2005; Coric 2012).

A number of empirical studies have investigated the validity of Great Moderation. A vast majority of these papers have focused on US. For instance, Kim and Nelson (1999) (for 1953-1997 period), McConnell and Perez-Quiros (2000) (for 1953-1999 period) and Chauvet and Potter (2001) (for 1959-2000 period) are among the studies that provide empirical support in this context. With regard to studies on other countries, Hakura (2007) and Coric (2012) have investigated this issue for a broad range of countries, respectively for 1970-2003 and 1961-2007 periods. Both studies found evidence of declining volatility in most of the countries. Buch, Doepke and Pierdzioch (2004)

(c) The Author(s) 2019. This article is distributed under the terms of the Creative Commons Attribution 4.0 International License (http://creativecommons.org/licenses/by/4.0/), which permits unrestricted use, distribution, and reproduction in any medium, provided you give appropriate credit to the original author(s) and the source, provide a link to the Creative Commons license, and indicate if changes were made. 
analyzed the issue for Germany and found declining volatility after the unification of East and West Germany. More recent studies have analyzed whether great moderation ended due to volatility observed during the global financial crisis in 2008/2009 that was triggered by malfunctioning of mortgage credit markets in US (Clark 2009; Darné et al. 2018).

In the theoretical literature, sources of the great moderation have been heatedly discussed. Several hypotheses have been put forward. First, termed as inventory hypothesis, improvement in inventory management, just in time production and digitalization of economy is referred to as the major source of output smoothing (Zarnowitz and Moore 1986; McConnell and Perez-Quiros 2000; Owyang et al. 2008; Kahn et al. 2002) Second, success of the FED (Federal Reserve Board)'s monetary policy in creating price and financial stability using proper tools such as money supply, interest rate, fine tuning and management of expectations efficiently has contributed significantly to the stabilization (Taylor 1999; Boivin and Giannoni 2006). Third, termed as good luck hypothesis, simple smaller random shocks that occurred in costs, energy and commodity prices after the oil crisis (1970s) might have created such a moderation (Ahmed et al. 2004; Carlino et al. 2003; Owyang et al. 2008; Stock and Watson 2002, 2003, 2005).

In this study, we investigate the current validity of Great Moderation for OECD (Organization of Economic Cooperation and Development) economies. The period of analysis runs from 1962Q2 to 2018Q3. The addressed research questions are as follows: (i) is the Great Moderation still valid? and (ii) is there any other output moderation/ amplification after the global financial crisis in 2008/09?

We hypothesize that the global financial crisis (2008/09) might have been highly influential on the volatility patterns. This might happen because countries took high precautionary actions after 2009 against the speculative fluctuations. Government policies became more regulatory; interventions have been set to limit free fluctuation of economic/financial variables. Particularly, in banking and real estate sector, the regulations have been increased. Uncontrolled credit lending and artificially created asset price bubbles are avoided. Monetary and fiscal policies are successfully designed in a way to minimize the cyclical swings. Central banks take policy actions with great precaution, such that policy shocks such as unanticipated monetary expansion, too low interest rates are avoided. Moreover, in the last decade, the world has been experiencing a technological revolution with a sudden increase in the productivity driven by the advancement of artificial intelligence systems. All these might have led to increase in productivity and great stabilization of output in the most recent period.

Our dataset covers aggregate OECD cycle and 26 member countries. In terms of methodology, it has mainly been used as the measures of conditional and unconditional volatility and algorithms of structural break detection, namely, Inclan and Tiao (1994) procedure and $\mathrm{ARCH}$ (autoregressive conditional heteroscedasticity model) (Engel 1982).

Novelty of the paper comes from the fact that, to the best of our knowledge, it represents one of the first attempts to analyze the post-crisis (2008/09) period and shows evidence for another Great Moderation that occurred at about 2010Q1. The period after this break date is characterized by much stable output evolution. Also, the possible reasons for such a new moderation are discussed throughout the text. 
The organization of the paper is as follows: in the following sections, data and methods, results, discussion and conclusion are provided, respectively.

\section{Data and methods}

A primary task in our analyses is to estimate the business cycles. In terms of data, quarterly GDP series (with constant 2010 prices in US dollars, seasonally adjusted and in natural logarithms) are employed.

There are a number of business cycle extraction methods in the literature (Baxter and King 1999; Christiano and Fitzgerald 2000; Hodrick and Prescott 1997).

Baxter-King and Christiano-Fitzgerald filters are designed to remove high- and lowfrequency movements in the series and extract directly the cycles that fluctuate between 1.5 years and 8 years. The disadvantage of these techniques is that implementation requires a loss of at least few observations from the start and end points of the periods. In contrast, Hodrick-Prescott filter does not require this. It filters to smooth the series, obtain a long-term trend and calculate the fluctuations by computing the deviation of actual series from this long-term trend. Given its well-known merits, Hodrick-Prescott filtering has become one of the most widely used filters (Duran 2013, 2014, 2015; Buch et al. 2004; Buch and Scholetter 2013). It enables to capture the non-linearity in longterm trend. It is argued to be more accurate compared to other methods. It is intuitive and simply applied. It does not give rise to artificial fluctuations and breaks. Since our target is to estimate the structural breaks, it is useful to adopt this technique for the advantages explained above.

Then, the following HP (Hodrick and Prescott) (1997) filter is applied: ${ }^{12}$

$$
\min \sum_{t=1}^{T}\left(x_{t}-\tau_{t}\right)^{2}+\theta \sum_{t=2}^{T}\left[\left(\tau_{t+1}-\tau_{t}\right)-\left(\tau_{t}-\tau_{t-1}\right)\right]^{2}
$$

where $x$ is a time series variable and $\tau_{t}$ is its long-term trend. Minimization of the term above helps extracting the fluctuations of $x$ around its trend. To be able to observe the tendency of output instability and test the possible structural breaks, three main methods are used.

The first method is exploring the evolution of volatility. Two types of volatility measures are adapted: conditional and unconditional volatility. To start with unconditional volatility, given that $y$ is the cyclical component of quarterly real GDP (gross domestic product) (HP de-trended), unconditional volatility is the standard deviation of $y$ over a time period (Carlino et al. 2003):

Unconditional volatility $=\sigma(y), \sigma:$ standard deviation

The conditional volatility is calculated by referring to the magnitude of fluctuations in shocks to GDP. To do so, the following autoregressive (AR(8)) process is applied (Stock and Watson 2002, 2003, 2005; Carlino et al. 2003):

$$
y_{t}=\delta_{0}+\delta_{1} y_{t-1}+\cdots \ldots+\delta_{8} y_{t-8}+\epsilon_{t} \text { where conditional volatility }=\sigma(\epsilon), \sigma: \text { standard deviation }
$$

\footnotetext{
${ }^{1}$ The dataset is obtained from OECD statistical database available at: https://stats.oecd.org/.

2 The formulation is adapted from Duran (2014).
} 
Conditional and unconditional volatility are considered in a dynamic manner. They are calculated on a yearly basis and, hence the evolutions of both volatility measures can be observed in graph $2 \mathrm{~b}$. Lag length of eight quarters is selected since it provides adequately long memory ( 2 years). Another reason for selecting eight quarters is to provide standard and comparable lag length across different regressions.

As a second method, we detect the structural breaks using the following technique developed by Inclan and Tiao (1994) and used by Buch et al. (2004) ${ }^{3}$ :

$$
D_{k}=\left(\frac{C_{k}}{C_{T}}-\frac{k}{T}\right) \sqrt{T / 2}
$$

$\left|D_{k}\right|$ represents the test statistics used in examining the possible break at quarter k. $T$ represents total time periods (226 quarters in our case). $C_{k}=\sum_{t=1}^{k}\left(y_{\text {oecd }}\right)^{2}$ represents square of OECD cyclical component $\left(y_{\text {oecd }}\right)$ until the quarter $k$, whereas $C_{T}=\sum_{t=1}^{T}\left(y_{\text {oecd }_{t}}\right)^{2}$ denotes total sum of squares. The critical values of $\left|D_{k}\right|$ are obtained from Inclan and Tiao (1994).

As for the third method, ARCH model is used to check the robustness of break dates (Engel, 1982; Buch et al. 2004). It is stated in the following model,

$$
\begin{aligned}
& y_{t}=\delta_{0}+\delta_{1} y_{t-1}+\cdots \ldots+\delta_{8} y_{t-8}+\epsilon_{t} \text { (mean equation) } \\
& \emptyset_{t}^{2}=\partial+\epsilon_{t-1}^{2}+\beta_{1} \text { timedummy }_{t}+\beta_{2} \text { timetrend }_{t}+\aleph_{t} \text { (variance equation) }
\end{aligned}
$$

where $\emptyset_{t}$ is the conditional output volatility, $\epsilon_{t-1}$ is the ARCH component. Time dummies represent the possible dates (quarters) used to test the time breaks. Time trend is also added to capture the breaks that evolve gradually over time, representing the breaks not in discrete form.

\section{Results}

First, it is displayed in Fig. 1 below the evolution of estimated economic cycle for the total OECD area. The fluctuations exhibit the percentage deviations of GDP from its long-term trend.

It can preliminarily be observed that in 1960 s, volatility had been moderate, however, it rose significantly during the 1970s (possibly due to oil shock) and remained high until mid-1980s after which amplitude of fluctuation lowered until 2008/09 crisis. During the $2008 / 2009$ crisis, volatility greatly increased. This has led to many arguments claiming the end of Great Moderation by 2008 (Clark 2009; Darné et al. 2018). However, we observed a much controversial fact that, after 2010, the reduction in amplitude was far greater, representing the most stable GDP period.

To explore the structural breaks in volatility, Fig. 2a presents Inclan-Tiao test statistics $\left(D_{k}\right)$ and its critical values at $10 \%, 5 \%$ and $1 \%$ levels. The gray shaded periods represent the time intervals during which $\left(D_{k}\right)$ is statistically significant. In Fig. 2b, the evolution of conditional $\sigma(\in)$ and unconditional volatility $\sigma(y)$ is presented using a rolling window of four quarters ( 1 year). Finally, the increase/decline in volatility before and after the break

\footnotetext{
${ }^{3}$ This formula is adapted from Inclan and Tiao (1994) and Buch et al. (2004) study.
} 


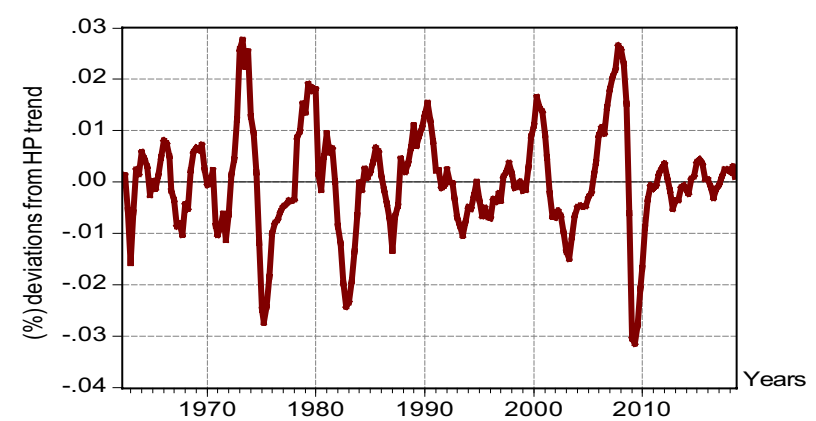

Fig. 1 OECD HP growth cycle

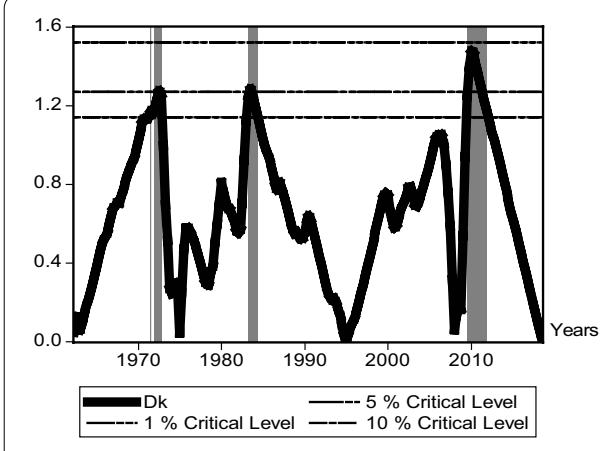

a Inclan-Tiao Test

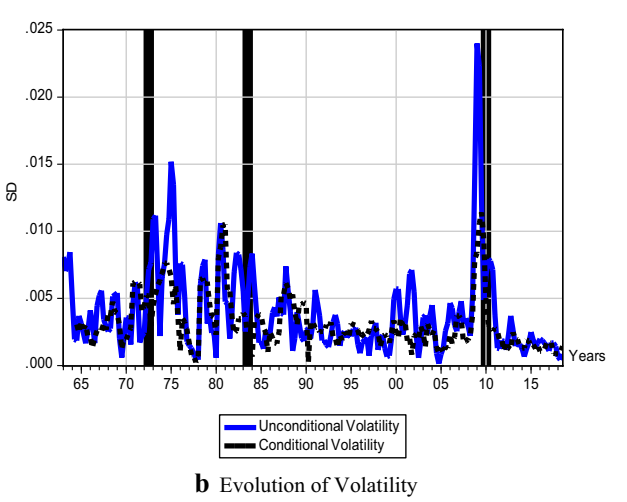

Fig. 2 Break dates and evolution of volatility

dates is summarized in Table 1. Several remarkable results appear to emerge from these analyses.

First, it has been found that the most significantly detected break quarters are 1972Q3 (significant at 5\%), 1983Q3 (significant at 5\%) and 2010Q1 (significant at 1\%). It is worth spending some theoretical and political words on the relevance of the breaks.

To start with the first one, in the prior period (1962-1972), the level of volatility was quite moderate. The well-functioning capitalist system during 1960s, stimulation of domestic demand and stabilization of economies after the Second World War, increasing Fordist-type mass production, exchange rate stability brought on by the Bretton Woods

Table 1 Inclan-Tiao test results, break dates and volatilities

\begin{tabular}{|c|c|c|c|}
\hline Break dates & Period & $\begin{array}{l}\text { Unconditional volatility } \\
(S D \times 100)\end{array}$ & $\begin{array}{l}\text { Conditional } \\
\text { volatility } \\
(S D \times 100)\end{array}$ \\
\hline 1972Q3 & 1962Q2-1972Q2 & 0.61 & 0.35 \\
\hline 1982Q3 & 1972Q3-1983Q2 & 1.53 & 0.53 \\
\hline \multirow[t]{2}{*}{ 2010Q1 } & 1983Q3-2009Q4 & $\begin{array}{l}1.04 \text { (excluding 2008/09 crisis, } \\
\text { volatility: 0,83) }\end{array}$ & $\begin{array}{l}0.36 \text { (exclud- } \\
\text { ing 2008/09 } \\
\text { crisis, volatil- } \\
\text { ity: } 0.30 \text { ) }\end{array}$ \\
\hline & 2010Q1-2018Q3 & 0.40 & 0.17 \\
\hline
\end{tabular}

Error terms are calculated on the basis of $A R(8)$ process 
system are among the plausible reasons for low volatility during this period. After the World War II, there was an excess demand for domestic goods in markets, which gave rise to an increase in entrepreneurship and output volume. Hence, under political and economic stability climate, firms invested a large amount in a smooth fashion which resulted in stability.

By 1970s, however, things started to change. Domestic demand almost came to a halt. Profit rates have started to fall. Thus, firms have started to search for higher returns abroad. Transportation facilities and ICT were developed well. Hence, foreign shocks to costs, particularly in oil prices, triggered fluctuations. Hence, we detect a break in 1972Q3 after which the volatility increased significantly. In Table 1, it is stated that unconditional volatility of OECD cycle [SD (standard deviation)] increased from 0.61 (in pre-break period) to 1.53 (in post-break period).

After the 1970s, the pattern of volatility once more changed. In mid-1980s, another structural break was detected by a large stream of scholars. According to our calculations, the break is evident at 1983Q3. Unconditional volatility declined from 1.53 (in pre-break period) to 1.04 (in post-break period). This break is argued to occur for several economic and political reasons. First, firms have learned better the inventory management and planning. Hence, following this break, firms started to smooth the output as they were able to produce just in time. Second, central banks started to apply better monetary policies and fine tuning. Accuracy of decisions on interest rate, money supply and other policy instruments led to stabilization of not only prices but also output. Third, the fact that simple smaller random shocks occurred after 1980 might have created a smooth output process, termed as good luck hypothesis. The reasons above have been discussed by the related literature (Zarnowitz and Moore 1986; McConnell and Perez-Quiros 2000; Owyang et al. 2008; Kahn et al. 2002; Coric 2012).

The stability, however, ended by 2008/2009 global economic crisis, as also discussed by other scholars (Clark 2009; Darné et al. 2018). We detect a very significant break at 2010Q1. Indeed, before the break, (in 1983-2010 period), the unconditional volatility level was 1.04, it declined to 0.4 after the break (for the period 2010-2018). Hence, one may therefore argue that the OECD economy had been experiencing the most stable period between 2010Q1 and 2018Q3 (almost 9 years). One important notice is that since high volatility during the global crisis might have created an artificial break in 2010Q1, we excluded 2008/2009 years and calculated again the levels of volatility. The results remain consistently the same. Once we exclude 2008/2009 crisis period from our analyses, pre-break period (1983-2007) volatility becomes 0.83 (instead of 1.04) which is still far above the post-break (2010-2018) volatility that is 0.4 . This fact is also reported in Table 1.

Why such stabilization was observed might be due to several reasons. First, governmental policies have a strong tendency towards regulating banking and financial sector coupled with limitations to mortgage sub-prime credit lending and exchange of mortgage-backed securities. After the economic disaster in 2008/09, policy makers have had a big fear of uncontrolled lending of credits and, thus, artificially created asset bubbles. This tight regulation policy might have created a decline in economic and financial volatility. 
Second, monetary policy was successfully designed so that it might help minimize the fluctuations. Central banks started to prefer precautionary actions. Hence, unexpected monetary shocks, i.e., too low interest rates, could be avoided. Expectations were managed much better. All modern instruments of central banking were properly used.

Third, another plausible reason is referred to as the achievement of fiscal programs that rose after the crisis. From a Keynesian perspective, government expenditures increased considerably, in the form of fiscal aid programs, tax lowering, etc. These programs might have stabilized the domestic demand and, hence, smoothed the output.

Fourth, finally, a last hypothesis regards the technological progress. In the last decade, electronic systems and artificial intelligence were intensively developed. It, thus, created a positive shock and made economic activity/transactions much faster (such as use of electronic shopping, electronic systems in bureaucracy) (Ahmed et al. 2004; Carlino et al. 2003, 2013; Owyang et al. 2008; Stock and Watson 2002, 2003, 2005). As a result, it is likely that the jump in economic efficiency contributed to the rapid growth in productivity and moderation of business cycle volatility.

Having reached our main results, we apply five different analysis of robustness.

First, the significance of break in 2010 should also be tested at the country level that can provide detailed info on the generality of the break. To do so, we apply exactly the same procedure of Inclan-Tiao test and implement it for each country. The results are summarized in Table 2. Only the most significant breaks are reported that represent the highest value in each separate episode of significant Inclan-Tiao test statistics.

It is observed that break at about 2010Q1/2009Q4 is evident in 14 countries. These countries are quite big in economic size. It includes US, UK, Germany, Japan, France, Turkey, Mexico, Denmark, Belgium, Finland, Canada, Switzerland and the Netherlands. They represent about $81 \%$ of the total OECD GDP. So, the detected break is valid also for most countries in OECD which are quite big in economic size and therefore, they are well representative of the OECD world. Other break dates during 1970s and 1980s are consistent with the previous findings.

Second robustness check we concern with is the relative impact of 2010Q1, 1983Q3 and 1972Q3 break quarters in each country. To pursue such an analysis, we apply an $F$ test that examines the equality/inequality of variance in each country's economic cycle between pre- and post-break periods.

The results are presented in Table 3. It is clearly seen that the most influential break quarter is the one at 2010Q1. It is statistically significant in 24 countries (out of 26). When we compare pre-break/post-break ratios, which represents the magnitude of break, 2010Q1 has the highest value compared to other break dates. Its cross-country average is 2.17 which means that the volatility has fallen below its half level compared to the pre-break period. The other break dates are also statistically significant, but the impact is much lower. The cross-country average of pre-break/post-break ratio is 1.21 for 1982Q3 and 0.97 for 1972Q3.

As a third robustness analysis, we apply several placebo structural break tests seen in Table 4. Three different quarters (1973Q2, 1985Q4, 1998Q2) were randomly selected. They are assumed as structural breaks and the significance is tested using $F$ test. The corresponding $p$ values of test statistics are reported for each candidate break quarter. As an outcome, we observe that none of the randomly selected candidate break dates 
Table 2 Country-level Inclan-Tiao test

\begin{tabular}{|c|c|c|c|}
\hline Country & $2000-2018$ & $1980-2000$ & 1960-1980 \\
\hline Australia & - & 1992Q3 & - \\
\hline Austria & - & 1980Q1 & 1976Q2 \\
\hline Belgium & 2009Q4 & 1993Q4, 1980Q3 & - \\
\hline Canada & 2010Q2, 2000Q4 & 1993Q1, 1983Q4 & - \\
\hline Denmark & 2010Q1 & 1987Q2 & - \\
\hline Finland & 2010Q1 & 1988Q3 & - \\
\hline France & 2010Q2 & 1997Q1, 1990Q4 & 1976Q4 \\
\hline Germany & 2010Q2 & 1980Q2 & 1976Q1 \\
\hline Greece & - & 1991Q1 & 1976Q4, 1972Q1,1975Q3 \\
\hline Iceland & - & 1988Q2, 1984Q1 & 1970Q1 \\
\hline Ireland & 2006Q2 & - & - \\
\hline Italy & - & 1993Q4,1980Q4 & - \\
\hline Japan & 2009Q4 & - & 1975Q1 \\
\hline Korea & - & 1999Q1,1982Q3 & - \\
\hline Luxembourg & - & - & 1976Q1 \\
\hline Mexico & 2009Q4 & 1996Q3 & 1976Q1 \\
\hline Netherlands & 2009Q3 & 1992Q1, 1983Q1 & 1975Q3, 1966Q1 \\
\hline New Zealand & - & 1993Q2 & - \\
\hline Norway & 2000Q1 & 1998Q2, 1993Q4 & 1987Q2, 1979Q2 \\
\hline Portugal & - & 1992Q1 & - \\
\hline Spain & 2006Q4 & - & 1976Q4 \\
\hline Sweden & 2006Q2 & - & - \\
\hline Switzerland & 2009Q2 & 1981Q4 & - \\
\hline Turkey & 2010Q3 & 1993Q1 & - \\
\hline United Kingdom & 2010Q1 & 1990Q2 & - \\
\hline United States & 2010Q1 & 1983Q3 & - \\
\hline
\end{tabular}

is widely evident. For instance, it has been found that, in 1973Q2, only 11 countries, in 1980Q4 only 4 countries, in 1998Q2 only 10 countries (out of 26) have experienced a significant structural break in volatility.

The fourth robustness control regards the following fact: country-specific random shocks are important and needs to verify whether the significance of break at 2010Q1 is still valid under these shocks. The shocks may arise for a number of economic and political reasons, i.e., sudden jump in costs, energy prices, natural disasters, war, etc. To do so, we first extract the country-specific shocks by employing the following autoregressive equation for each country:

$$
y_{t}=\vartheta_{0}+\vartheta_{1} y_{t-1}+\cdots \ldots+\vartheta_{4} y_{t-4}+\theta_{1} y_{\text {oecd }, t-1}+\cdots \ldots+\theta_{4} y_{\text {oecd }, t-4}+\exists_{t}
$$

where $y$ represents a business cycle of a country and, $y_{\text {oecd }}$, denotes the OECD's aggregate cycle. Hence, with the equation above, country level and global economic drivers are controlled. Hence, $\exists$ represents country-specific shocks, net of global and countryspecific movements.

Then, we test the significance of break dates (2010Q1, 1983Q3, 1972Q3) in countryspecific shocks. We compute the pre-break/post-break ratio and corresponding $F$ statistics for each country. The pre-break/post-break ratio represents the magnitude of the break in the volatility. The results are summarized in Table 5. It is observed that 


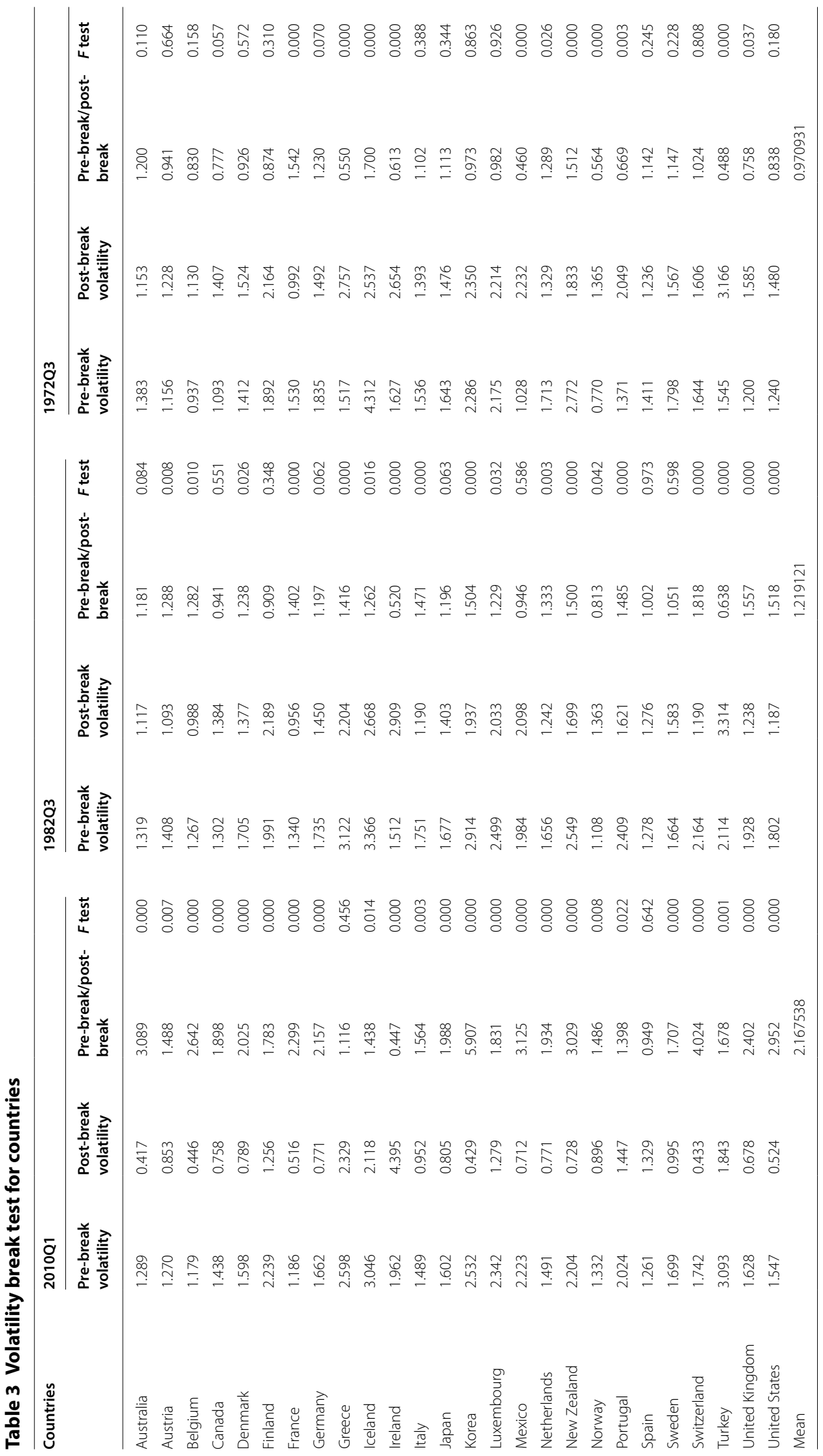


Table 4 The results of Pre-break/post-break $\boldsymbol{F}$ Test's $\boldsymbol{P}$ values (placebo breaks)

\begin{tabular}{|c|c|c|c|}
\hline Country & 1973Q2 & 1985Q4 & 1998Q2 \\
\hline Australia & 0.173 & 0.543 & 0.450 \\
\hline Austria & 0.688 & 0.664 & $0.009^{* * *}$ \\
\hline Belgium & 0.173 & 0.235 & 0.501 \\
\hline Canada & 0.104 & 0.195 & 0.967 \\
\hline Denmark & 0.997 & 0.380 & 0.158 \\
\hline Finland & 0.396 & 0.870 & $0.060^{*}$ \\
\hline France & $0.000^{* * *}$ & $0.069^{*}$ & 0.277 \\
\hline Germany & $0.034^{* *}$ & 0.309 & 0.199 \\
\hline Greece & $0.048^{* *}$ & 0.113 & $0.026^{* *}$ \\
\hline Iceland & $0.000^{* * *}$ & $0.003^{* * *}$ & $0.004^{* * *}$ \\
\hline Ireland & $0.000^{* * *}$ & 0.690 & 0.187 \\
\hline Italy & 0.338 & 0.567 & $0.000^{* * *}$ \\
\hline Japan & $0.016^{* *}$ & 0.118 & 0.754 \\
\hline Korea & 0.644 & 0.244 & 0.999 \\
\hline Luxembourg & 0.962 & 0.565 & 0.123 \\
\hline Mexico & $0.000^{* * *}$ & $0.046^{* *}$ & 0.154 \\
\hline Netherlands & $0.044^{* *}$ & 0.943 & $0.001^{* * *}$ \\
\hline New Zealand & $0.001^{* * *}$ & 0.831 & 0.360 \\
\hline Norway & $0.000^{* * *}$ & $0.024^{* *}$ & 0.420 \\
\hline Portugal & 0.179 & 0.108 & $0.047^{* *}$ \\
\hline Spain & 0.255 & 0.219 & 0.664 \\
\hline Sweden & 0.385 & 0.480 & 0.783 \\
\hline Switzerland & 0.552 & 0.301 & $0.001^{* * *}$ \\
\hline Turkey & $0.000^{* * *}$ & 0.199 & $0.007^{* * *}$ \\
\hline United Kingdom & 0.303 & 0.620 & 0.135 \\
\hline United States & 0.957 & 0.215 & $0.000^{* * *}$ \\
\hline
\end{tabular}

*represents statistical significance at $10 \%,{ }^{* *}$ at $5 \%,{ }^{* * *}$ at $1 \%$

the most significant break is observed at 2010Q1 at which cross-country average of pre-break/post-break volatility ratio is 1.99 . It basically means that output volatility has fallen to half level following break at 2010. The two other break dates are also significant but to a less extent. So, the ratio is, respectively, 1.37 and 1.25 for the breaks at 1982Q3 and 1972Q3.

The same picture is also true for inferential $F$ statistics. The detected break is significant for 24/26 for 2010Q1, 23/26 for 1982Q3 and 1972Q3. Thus, having the set of evidence above, it is safe to argue that 2010Q1 represents a robust and more significant break than others, even under random country-specific shocks.

A fifth way to ensure the robustness of the detected break quarters is to run once the ARCH model [explained in Eqs. (5) and (6)] and test the significance of the break dates that are detected by Inclan and Tiao (1994) test. Moreover, not only the discrete (one time) break is tested but also structural breaks under the gradual change are tested by adding a time trend in the variance equation. The results are presented in Table 6. As seen in the last four rows, the most robust break date occurs at 2010Q1, 


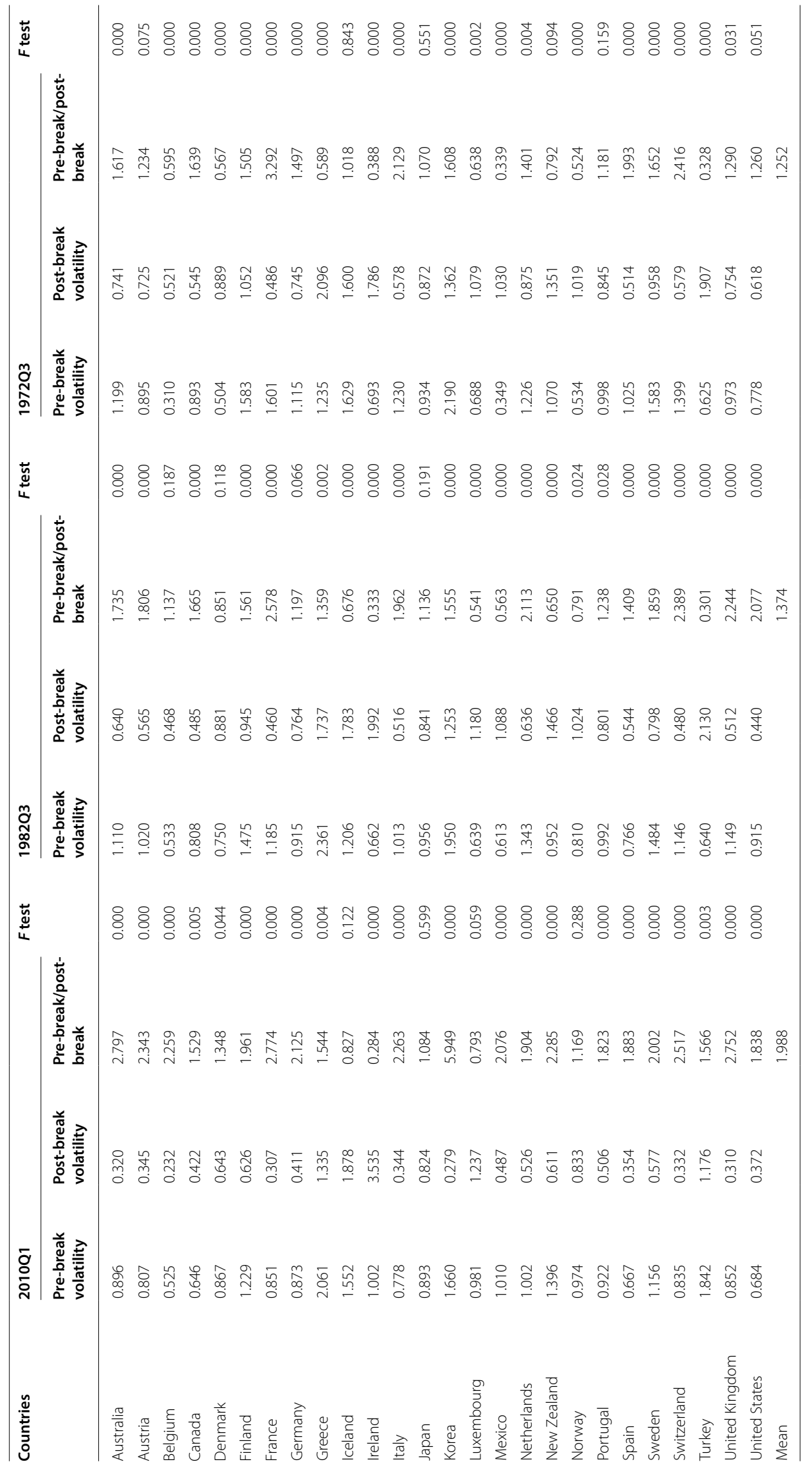


Table 6 Robustness check of the break dates, ARCH model

\begin{tabular}{|c|c|c|c|c|c|c|}
\hline & Model 1 & Model 2 & Model 3 & Model 4 & Model 5 & Model 6 \\
\hline \multicolumn{7}{|c|}{ Mean equation } \\
\hline Constant & -0.00009 & 0.00011 & 0.00007 & 0.00019 & 0.00002 & 0.00004 \\
\hline$y_{1}$ & $1.259^{* * *}$ & $1.270^{* * *}$ & $1.262^{* * *}$ & $1.276^{* * *}$ & $1.222^{* * *}$ & $1.238^{* * *}$ \\
\hline$y_{2}$ & $-0.280^{* * *}$ & $-0.267^{* *}$ & $-0.251^{* *}$ & $-0.256^{*}$ & $-0.241^{* *}$ & $-0.254^{* *}$ \\
\hline$y_{3}$ & -0.147 & -0.138 & $-0.185^{*}$ & -0.159 & $-0.181^{*}$ & -0.182 \\
\hline$y_{4}$ & 0.036 & 0.048 & 0.056 & 0.053 & 0.055 & 0.060 \\
\hline$y_{5}$ & $-0.187^{*}$ & -0.177 & -0.120 & -0.131 & -0.200 & -0.180 \\
\hline$y_{6}$ & $0.203^{*}$ & 0.165 & 0.099 & 0.111 & 0.242 & 0.211 \\
\hline$y_{7}$ & -0.056 & -0.020 & 0.029 & 0.015 & -0.094 & -0.078 \\
\hline$y_{8}$ & -0.055 & -0.041 & -0.070 & -0.048 & -0.051 & -0.047 \\
\hline \multicolumn{7}{|c|}{ Variance equation } \\
\hline Constant & $0.000011^{* * *}$ & $0.000015^{* * *}$ & $0.000019^{* * *}$ & $0.000022^{* * *}$ & $0.000013^{* * *}$ & $0.000017^{* * *}$ \\
\hline $\begin{array}{c}\mathrm{ARCH} \text { com- } \\
\text { ponent }\end{array}$ & 0.236159 & $0.290468^{* *}$ & $0.225177^{*}$ & $0.342106^{* * *}$ & $0.157000^{*}$ & $0.153658^{*}$ \\
\hline d1972Q3 & -0.0000004 & $0.0000095^{* *}$ & & & & \\
\hline d1983Q3 & & & $-0.0000123^{* * *}$ & -0.0000082 & & $-0.0000070^{* * *}$ \\
\hline d2010Q1 & & & & & $-0.0000111^{* * *}$ & \\
\hline Trend & & $-0.0000001^{* * *}$ & & $-0.0000001^{*}$ & & $0.0000000^{* *}$ \\
\hline
\end{tabular}

which is evident regardless of whether time trend is added or not. The other breaks are rather moderately evident.

\section{Discussion}

The newest stabilization after 2010 should be discussed in terms of the economic and political reasons behind.

As a first reason, after the global economic crisis (2008/09), many countries have started to regulate their banking and financial sector along with limitations to mortgage sub-prime credit lending and to the trade of mortgage-backed securities. This regulation process might have led to a decline in fluctuation in financial and output markets. After the dramatic experience of global downturn in 2008/09 economic crisis, governments have had a fear of uncontrolled and massive lending of credits and artificially created asset bubbles. In order not to experience such a global crisis again, economic policies in many countries have been designed in a precautionary and protectionist fashion. In banking and real estate sectors, various restrictions and regulations have been imposed.

Second, monetary policy is applied with a great care on fluctuations. Hence, unexpected monetary shocks, i.e., interest rates below equilibrium rate, etc., are avoided. Expectations are managed using all modern instruments of central banks. As a result, not only price stability is achieved but also output smoothing.

Third possible reason might be the success of fiscal programs and policies launched after the crisis. In line with a Keynesian perspective, rise in government expenditures might have stabilized the domestic demand, hence, smoothed the output.

Fourth, in the last 10 years, artificial intelligence and software systems have rapidly developed. This might have led to a positive shock and significant increase in efficiency and velocity of economic activity (such as use of electronic shopping, 
electronic systems in bureaucracy) (Ahmed et al. 2004; Carlino et al. 2003; Owyang et al. 2008; Stock and Watson 2002, 2003, 2005). As an outcome, improvement in productivity may be regarded as a driver of current stabilization.

In other words, there has been a quite important rise in productivity in economic life in almost all sectors. Particularly in ICT sector, industry, services, logistics and e-commerce, the World has been experiencing a rapid improvement in efficiency and velocity. This helps smoothing the output as technological advancements make possible the production to be totally flexible, customized and efficient (i.e., in just a timely manner) (Zarnowitz and Moore 1986; McConnell and Perez-Quiros 2000; Owyang et al. 2008; Kahn et al. 2002; Coric 2012).

\section{Conclusions}

In this article, we provide new and novel evidence for a more recent and greater moderation of output volatility in OECD countries compared to the well-known one during mid-1980s.

It has mainly been used as the measures of conditional and unconditional volatility and procedures of structural break detection (Inclan-Tiao and ARCH model).

It has been shown that output is greatly stabilized following the structural break at 2010Q1, after the global economic crisis of 2008/09. To the best of our knowledge, such a break is shown for the first time in the related literature. Moreover, the output stabilization at 2010Q1 is robustly evident for 24 (out of 26) OECD countries.

From a political standpoint, governments should be aware of this fact and contribute to the continuation of stability process. The capital flows should be dealt with great care. Free flow and uncontrolled trade of assets should be avoided. Exchange rate and inflation stability should be maintained. There is indeed a need for government intervention and regulation in capital and output market. In these ways, the recently experienced moderation of volatility can be sustained.

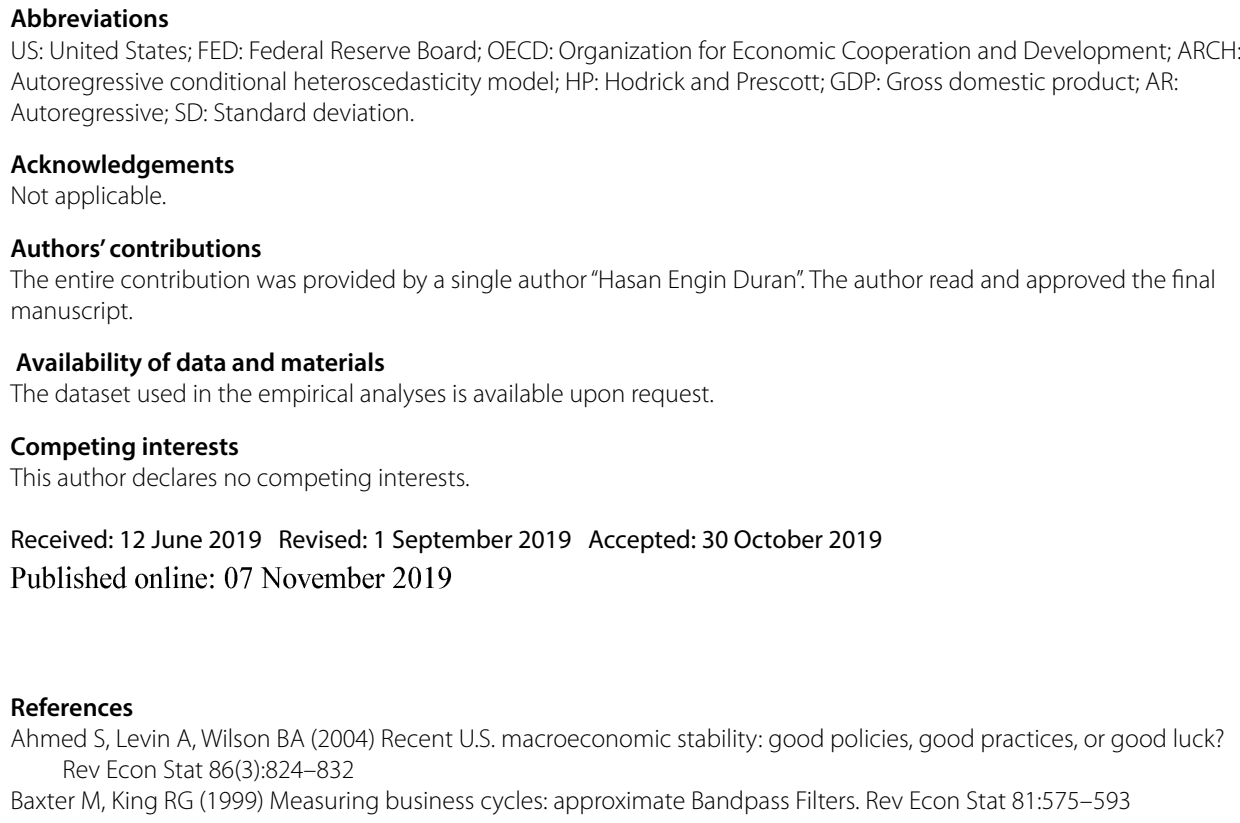


Bernanke B (2004) The Great Moderation. Speech at the meetings of the Eastern Economic Association, Washington, D.C., February 20. http://www.federalreserve.gov/boarddocs/speeches/2004/20040220/default.htm

Boivin J, Giannoni MP (2006) Has monetary policy become more effective? Rev Econ Stat 88(3):445-462

Buch CM, Scholetter M (2013) Regional origins of employment volatility: evidence from German states. Empirica 40:1-19

Buch CM, Doepke J, Pierdzioch C (2004) Business cycle volatility in Germany. Ger Econ Rev 5(4):451-479

Carlino G, Defina R, Sill K (2003) Post War Changes in Employment Volatility: New Evidence From State/Industry Panel Data, Growth Volatility. Working Papers 03-18, Federal Reserve Bank of Philadelphia

Carlino G, Defina R, Sill K (2013) The long and large decline in state employment growth volatility. J Money Credit Bank 45(2-3):521-534

Chauvet M, Potter S (2001) Recent changes in the U.S. business cycle. Staff Reports 126 Federal Reserve Bank of New York Christiano L, Fitzgerald J (2000) The Band Pass Filter. Int Econ Rev 44(2):435-465

Clarida R, Gali J, Gertler M (2000) Monetary policy rules and macroeconomic stability: evidence and some theory. Q J Econ 115:147-180

Clark TE (2009) Is the great moderation over? Federal Reserve Bank of Kansas City Economic Review. Fourth Quarter. pp $5-39$

Coric B (2012) The global extent of the great moderation. Oxford Bull Econ Stat 74(4):493-508

Darné O, Charles A, Ferrara L (2018) Does the Great Recession imply the end of the Great Moderation? International evidence. Econ Inq. 56(2):745-760

Duran HE (2013) Convergence of regional economic cycles in Turkey. Rev Urban Region Dev Stud 25(3):152-175

Duran HE (2014) Short run dynamics of income disparities and regional cycle synchronization in the U.S. Growth and Change 45(2):292-332

Duran HE (2015) Dynamics of business cycle synchronization in Turkey. Panoeconomicus 62(5):581-606

Engel RF (1982) Autoregressive conditional heteroscedasticity with estimates of the variance of United Kingdom inflation. Econometrica 50(4):987-1008

Hakura D (2007) Output Volatility and Large Output Drops in Emerging Market and Developing Countries. IMF Working Papers 07/114, International Monetary Fund

Hodrick R, Prescott EC (1997) Postwar US business cycles: an empirical investigation. J Money Credit Bank 29(1):1-16

https://stats.oecd.org/. Accessed 10 Nov 2018

Inclan C, Tiao GC (1994) Use of cumulative sum of squares for retrospective detection of changes in variance. J Am Stat Assoc 89:913-923

Kahn JA, McConnell MM, Perez-Quiros G (2002) On the causes of the increased stability of the U.S. economy. Federal Reserve Bank of New York. Econ Policy Rev 8(1):183-202

Kim CJ, Nelson CR (1999) Has the U.S. economy become more stable? A Bayesian approach based on a markov-switching model of the business cycle. Rev Econ Stat 81(4):608-616

McConnell M, Perez-Quiros G (2000) Output fluctuations in the United States: what has changed since the early 1980's? Am Econ Rev 90:1464-1476

Owyang MT, Piger J, Wall HJ (2008) A state-level analysis of the great moderation. Region Sci Urban Econ 38:578-589

Stock J, Watson M (2002) Has the business cycle changed and why? In: Gertler M, Rogoff SK (eds) NBER macroeconomic annual, vol 17. The MIT Press, Cambridge

Stock J, Watson M (2003). Has the business cycle changed: evidence and explanation. In: The Federal Reserve Bank of Kansas City Economic Symposium Conference Proceedings, Kansas City, pp 9-56

Stock J, Watson M (2005) Understanding changes in international business cycle dynamics. J Eur Econ Assoc 3:968-1006

Taylor J (1999) An historical analysis of monetary policy rules. In: Taylor J (ed) monetary policy rules. University of Chicago Press, Chicago

Zarnowitz V, Moore GH (1986) Major changes in cyclical behavior. In: Gordon RJ (ed) The American business cycle: continuity and change, national bureau of economic research conference on research in business cycles. University of Chicago Press, Chicago, pp 519-572

\section{Publisher's Note}

Springer Nature remains neutral with regard to jurisdictional claims in published maps and institutional affliations.

\section{Submit your manuscript to a SpringerOpen ${ }^{\circ}$ journal and benefit from:}

- Convenient online submission

- Rigorous peer review

- Open access: articles freely available online

- High visibility within the field

- Retaining the copyright to your article

Submit your next manuscript at $\boldsymbol{\nabla}$ springeropen.com 